\title{
Ironic imperialism: how Russian patriots are reclaiming postmodernism
}

\author{
Boris Noordenbos
}

Published online: 10 May 2011

(C) The Author(s) 2011. This article is published with open access at Springerlink.com

\begin{abstract}
This essay analyzes the recent appearance in Russian letters of ultranationalist fantasies about the restoration of Russia's imperial or totalitarian status. This new trend has its roots not only in the increasingly patriotic tone of Russian society and politics, but also in the dynamics of the literary field itself. 'Imperialist writers' such as Aleksandr Prokhanov and Pavel Krusanov have both revived and reacted against postmodern themes and motifs from earlier decades. Relying on the legacy of sots-art and stiob, the 'imperialists' advance a new model in Russia's postmodern tradition, one that is balanced on the very borderline between irony and ideological militancy. In playing the game of ambiguous fanaticism, these writers have been able to attract the attention of a broad and diverse public, and have moved from an intellectual periphery into the cultural mainstream.
\end{abstract}

Keywords Pavel Krusanov · Aleksandr Prokhanov · Dmitrij Bykov · Aleksandr Dugin $\cdot$ Russian postmodernism $\cdot$ Imperialism $\cdot$ Stiob $\cdot$ Sots-art

The last decade has witnessed the advent in Russian letters of megalomaniac fantasies about the restoration of Russia's imperial or totalitarian status. This trend has received various labels ('new imperial literature', 'radical literature', 'new political literature', etc.), and it appears in the work of very diverse writers, including Aleksandr Prokhanov, Dmitrij Bykov, and a group of authors called the 'Petersburg Fundamentalists'. 'Typically, the plots of these 'imperial novels'

\footnotetext{
1 The members of this group are Vadim Nazarov, Sergej Nosov, Nal' Podol'skij, Vladimir Rekšan, Il'ja Stogov, Pavel Krusanov and the philosopher Aleksandr Sekackij. In 2001 these writers and thinkers-all of whom were publishing their books (mostly in small print runs) at the Amfora publishing house in St.
}

B. Noordenbos $(\bowtie)$

University of Groningen, Groningen, The Netherlands

e-mail: B.Noordenbos@rug.nl 
involve a quest for a new political or moral authority, or a rehabilitation of former tyrants and dictators. In most cases the wished-for ideal is a strong Russian empire, curtained off from 'alien ideas' such as liberal democracy and free market capitalism.

Critics have been quick to suggest that the anti-Western and authoritarian tone of these books in one way or another mirrors the renewed self-confidence of the Russian political establishment in the new millennium. As one commentator observed in June 2001:

Прошло всего несколько месяцев [...] [и] все построились в шеренгу, втянули животы, посуровели, подняли подбородки и повернули их вправо.

[...] Морозный ветерок, поддувающий с кремлевских башен, расцветил носы и покрыл инеем усы неутомимых борзописцев (Prigodič 2001). ${ }^{2}$

It would be simplistic, however, to see this literary fashion merely as a conformist reaction mirroring a new assertiveness in the Kremlin. Since the beginning of the new century, the political programmes of the ruling elite have often been associated with nostalgia for Russia's status as a superpower. This shifting political environment has left more elbow room for nationalist thinkers. Among the most striking examples are the imperial prophecies of the philosopher Aleksandr Dugin, a major source of inspiration for the 'imperial writers'.

The popularity of the imperial movement in Russian letters also has its origins in the internal dynamics of the literary field, particularly in widespread fatigue with the irony, mockery, and pretentious intellectual games that were so prevalent in the postmodern culture of the nineties. For instance, during their first collective performance in 2001, the Petersburg Fundamentalists presented their own fanaticism as an antidote to the principles of the "Ложа Грибоедов" ["Lodge of mushroom-eaters"] and the "Орден Землеебов" ["Order of earth-fuckers"] (Latynina 2006), represented by Viktor Pelevin and Vladimir Sorokin. ${ }^{3}$ The frequent drug trips and sectarian sex-rituals in the literature of these popular, noncommittal postmodernists were to give way to a new literary impetuosity and radicalism.

\footnotetext{
Footnote 1 continued

Petersburg - attracted the attention of a broader public with a series of collective projects and public performances. They began to eulogize, in a half-serious tone, Russia's tradition of political iron-handedness, and in a letter to President Putin they even pleaded for the radical expansion of the borders of the Russian state. The artist Valerij Val'ran labeled these radicals the 'Petersburg Fundamentalists', a nickname they proudly adopted.

${ }^{2}$ Only a few months have passed [...] [and] all have lined up, pulled in their stomachs, put on strict faces, lifted their chins, and turned them to the right. [...] The frosty wind blowing from the Kremlin towers has reddened the noses of tireless hack writers and has covered their moustaches with rime.

3 'Mushroom-eaters' refers to the consumption of hallucinogenic drugs in some of Viktor Pelevin's novels. In Čapaev i Pustota [Buddha's little finger 1996] for instance, three mobsters, frightened by their own hallucinations after a taking a dose of mushrooms, run into the woods emptying their guns on whatever they imagine to be around. The 'Order of earth-fuckers' refers to Vladimir Sorokin's absurd novel Goluboe salo [Blue lard, 1999], in which one finds the extremely hierarchical society of the socalled earth-fuckers, gnome-like figures who worship, and copulate with, Mother Earth.
} 
On the surface, the 'new imperialists' appear to suggest a serious, reactionary alternative to the games and mockery of the nineties. They strive to rehabilitate the political significance of Russian literature, and, in the context of what Serguei Oushakine has described as a post-Soviet "feeling of disconnectedness" (Oushakine 2009, 21), their restorative fantasies and holistic mythologies may function as an opiate against grief. A closer look, however, reveals that the imperial trend itself has at least one foot in postmodernism: the aesthetically provocative styles and tropes of these 'conservative' writers sometimes overtly mimic those of Pelevin and Sorokin, and, as far as Krusanov and Bykov are concerned, serious political commitment is contaminated by substantial doses of irony and self-mockery.

To be sure, Russian postmodernism itself is by no means a monolithic and welldefined cultural paradigm. It has been characterized (in its literary, artistic, and philosophical variants) as a continuation of the traditions of the Silver Age (Lipovetsky and Borenstein 1999); as a reflection on the ruins of Socialist Realism (Groys 1992; 1995, 187-204); as the culmination of a long Russian tradition of "ideological simulations of reality" (Epstein 1995, 194); or as a concept that has been imported from the West (Dobrenko, the article in this issue). Whatever its origins may be, in the years following the collapse of the Soviet Union, postmodernism came to be widely associated not only with a liberal political agenda, but also with literary scandals and moral relativism. The new imperialists strip postmodern strategies of their relativist, anti-Soviet, and pro-Western aura. They smoothly incorporate postmodern genres and tropes into a radical politicalliterary program which, in a highly ambivalent tone, proposes to address the problem of Russia's future by autocratic, totalitarian, or 'imperial' means.

This essay focuses on a number of these imperialist writers, in particular Aleksandr Prokhanov and Pavel Krusanov. Initially occupying small niches in the literary field, around the turn of the millennium these writers succeeded in attracting the attention of an immensely broad and diverse public, and their books are now published by prestigious publishing houses. In the following essay we shall see how the imperialists, in their movement from the periphery to the centre of Russian cultural spheres, have revived and restructured older postmodern modes, such as sots-art and stiob. The imperialist movement, this essay contends, derives its sway and popularity not merely from the increasingly patriotic and anti-liberal tone of Russian society and politics, but also from the clever ways in which these writers merge ideological radicalism with postmodern irony, pastiche, and humor.

\section{Prokhanov's Gospodin Geksogen: pastiche or propaganda?}

A particularly exuberant manifestation of the emerging imperial fashion is the novel Gospodin Geksogen [Mister Hexogen, 2002] by the journalist and writer Aleksandr Prokhanov. Most of Prokhanov's earlier novels took on a programmatic character and reflected the patriotic, anti-liberal, and often anti-Semitic ideas expressed in his weekly newspaper Zavtra. Prokhanov's patriotism combines a conservative Orthodox impulse with reactionary communist elements, and blends them with a "mystical Stalinism" (Marsh 2007, 485). For a long time, this awkward mix of 
ideological orientations seemed especially welcome among a naïve senior audience that felt betrayed by the political and economic developments of the late twentieth century. In 2002, however, Prokhanov's reading public grew dramatically when the publishing house Ad Marginem, known for its liberal and postmodern bias, published the novel Gospodin Geksogen. The novel caused a furor which rose to fever pitch when the book was awarded the Russian National Bestseller Prize shortly after publication.

The book reinterprets the tumultuous political events of 1999 as a series of bizarre (and ultimately unsuccessful) conspiracies surrounding the restoration of the Soviet empire. Part of this project is a plan, hatched by ex-KGB officials, to maneuver into power an obedient puppet, the so-called Chosen One, whom the reader immediately recognizes as Vladimir Putin. The protagonist of the book, Viktor Andreevič Belosel'cev, is a convinced Stalinist and an obvious alter ego of the author, who is lured into these intrigues by his former KGB colleagues. Yet in the shadowy realm of Russian politics, a world that appears to be controlled by monstrous Jewish oligarchs, one can hardly distinguish genuine patriots from devious liberals. As the novel unravels, this Chinese box of political intrigues baffles both the protagonist and the reader.

The conspiratorial plot of Gospodin Geksogen is clearly meant to compensate for a perceived loss of collective values, norms, and social structures after the collapse of the Soviet Union. The demise of communism brought the protagonist's career to an abrupt end. He severed ties with his erstwhile KGB colleagues, most of whom became successful entrepreneurs during the early nineties. Moreover, Belosel'cev feels that the disintegration of the 'Red Empire' has obliterated a sense of national pride and belonging, and this post-Soviet sense of desolation has dominated his life since the early nineties: “Он жил как контуженый, попавший под фугасный взрыв. Конечности оставались целы, внутренние органы продолжали служить, но в психике оказались разорванными тончайшие волокна и нити, связывающие его с бытием"4 (Prokhanov 2002, 9).

During the greater part of the novel, the KGB conspiracy promises to 'repair' the effects of this individual and cultural 'shellshock' by secretly paving the way for the realization of Russia's supposed identity and mission (most importantly, the installation of a glorious and harmonious "вселенск[ая] импери[я]" ["universal empire"] (Prokhanov 2002, 429). In this respect, the novel displays what Serguei Oushakine has described as "the patriotism of despair": theories and conspiracies of belonging and identity that stem from a post-Soviet sense of dislocation. "[If] the perceived [post-Soviet] feeling of disconnectedness resulted in anything," Oushakine writes, "it was the incredible production of popular and theoretical discourses that exposed missing links and discovered hidden structures" (Oushakine 2009, 21). A secret agent by profession, Belosel'cev is indeed obsessed with revealing the obscure ties and the "загадочн[ые] замыс[лы]" ["mysterious designs"] (Prokhanov 2002, 105) that allegedly structure political life and recent history, and that might

\footnotetext{
4 "He was as if shell-shocked, as if he had survived a highly-explosive blast. His limbs remained intact, his internal organs continued to work, but in his psyche the tiniest filaments and threads connecting him with existence appeared to be broken."
} 
contain the key to the restoration of lost community, security, grace, and “территориальная целостность” [“territorial integrity”] (Prokhanov 2002, 33).

Prokhanov's nostalgia for lost unity, wholeness, and identity may seem a curiosity among the avant-garde publications of the publisher Ad Marginem. However, Prokhanov depicts dystopian post-communist society in a playful manner, using extravagant images seemingly at odds with his conservative program. In the book a demonic underground serpent, which symbolizes Russia's sell-out, hypnotizes the political establishment in the Kremlin; Yeltsin himself is literally a walking corpse, kept 'alive' artificially for the sole purpose of defending the business interests of the fraudulent elite; Russia's most prominent liberal journalists are unmasked as robots, radio-controlled by the CIA; and, on the last page of the novel, the 'Chosen One', the mystical agent of Russia's imperial revival, turns into a rainbow and evaporates into the blue sky.

These images established Prokhanov's reputation as a playful postmodernist. Some critics even read the book as an entertaining 'deconstruction' of nationalist pulp writing (for instance Ol'šanskij 2002), in the vein of Vladimir Sorokin's famous postmodern pastiches of naïve patriotic and Socialist Realist prose. Others objected that Prokhanov has always been a fanatic neo-Stalinist and anti-Semite. They argued that the author's poor writing skills and unconventional imagery should not be mistaken for postmodern experimentation or deconstruction. What was pastiche for Sorokin was serious prose in the case of Prokhanov (Kenžeev 2002), and while Sorokin's postmodernism was "intentional," Prokhanov, in contrast, intended to be "serious" (Aptekman 2006).

But it seems hard to maintain such distinctions based on the hypothetical intentions of the author. Prokhanov has declared himself an admirer of Sorokin's work. He praises the latter's experimentation with historiography and stylistic diversity, especially in Lëd [Ice, 2002] and Goluboe salo [Blue lard, 1999]. Although he denies any direct influence by Sorokin on his work, Prokhanov feels that they share a generally postmodern, sometimes psychedelic aesthetic, a mode of writing that fits the absurd realities of late- and post-Soviet society (personal conversation with the author, 3 November 2009). Prokhanov started to read Sorokin only after the publication of Gospodin Geksogen. It was his friends at the publishing house Ad Marginem who recommended this literature to him. ${ }^{5}$

Ad Marginem has not only altered Prokhanov's own reading behaviour, it has also drastically influenced the way Prokhanov has been read. The publisher of Sorokin's most scandalous novels, and also of Russian translations of Derrida, Lyotard, and Baudrillard, Ad Marginem has repeatedly foregrounded the experimental, avant-garde quality of Prokhanov's prose. As the critic Lev Danilkin observed in 2001: “[они] позиционируют Проханова как героинового Толстого или накокаиненного Фадеева" (Danilkin 2002). The director of Ad Marginem himself feels that Prokhanov's neo-Stalinism presents a welcome change to the anticommunist impulse in post-Soviet literature. Prokhanov, in his view, advances a

\footnotetext{
5 Prokhanov's more recent novels show Sorokin's influence. In The political scientist [Politolog, 2005], for instance, members of the Politburo engage in a Sorokinesque session of group sex.

6 "[they] are casting Prokhanov as Tolstoy on heroin or Fadeev on coke."
} 
refreshing radicalism and a uniquely Russian brand of madness (Ivanov and Aleksandrov 2002).

When discussing the enthusiasm of refined aesthetes and postmodernists for a 'red-brown' patriot like Prokhanov, we should not lose sight of the fact that Russian postmodernism has always been fixated on ideology. Whereas American 'Pop Art' embraced the symbols of popular mass culture, from the seventies onwards its Russian equivalent, sots-art, reflected on the tropes of Socialist Realism, an art form that, in the words of Boris Groys, "markets not things but ideology" (Groys 1992, 11). Sots-art reproduced the formal features of Socialist Realism in order to deconstruct its world view. In his famous stories in that genre, Sorokin, for instance, meticulously mimicked Socialist Realist or nationalist-conservative commonplaces and juxtaposed them with antagonistic semiotic systems that destroyed or nullified each other. However, in other sots-art works (for instance Komar and Melamid's paintings) the boundaries between the (nostalgic) reproduction and ironic deconstruction of Socialist Realist or Stalinist art are less clearly defined.

In a number of artistic expressions from the new millennium the opposition (already complex in sots-art itself) between skepticism and ideological commitment has eroded even further. Recently, Mark Lipovetsky has written extensively on the ways in which postmodern tropes are (mis)used in post-Soviet culture for the propagation of neo-traditionalist ideas and for the "rehabilitation" of Soviet myths (Lipovetsky 2008, 469-530, 720-755). We will shortly come back to this perspective, but for now it should be noted that Lipovetsky, alluding to the sotsart tradition, considers Prokhanov's work part of a new 'post-sots' movement, a “брак по расчету между постмодернизмом и соцреалистической мифологией”7 (Lipovetsky and Ėtkind 2008, 176). One could object, of course, that Prokhanov does not merely revive Socialist Realism. Instead, he expresses his anti-liberalism in fanatical slogan-like language which occasionally recalls Soviet and, in particular, (neo-)Stalinist, art. ${ }^{8}$ As far as the other component of post-sots is concerned, Prokhanov's "marriage with postmodernism" was at least to some extent prearranged by the efforts of his publisher. It is evident that Ad Marginem's logo on the cover of Prokhanov's book has thoroughly influenced the novel's reception.

\section{Krusanov's Amerikanskaja dyrka: the death of America and the revival of stiob}

The blurred borderline between postmodern irony and patriotic fanaticism is also prevalent in the novels of the Petersburg Fundamentalists' leader, Pavel Krusanov. Krusanov's first literary success, Ukus angela [The bite of an angel, 1999], is set in a vast Russian empire at an unspecified period, and chronicles the political career of the immensely brutal Eurasian dictator Ivan Nekitaev.

More illustrative for our purposes here, however, is the author's Amerikanskaja dyrka [The American hole, 2005], which centers upon a successful plan to destroy

\footnotetext{
7 "[a] marriage of convenience between postmodernism and Socialist Realist mythology."

8 Rosalind Marsh even compares Prokhanov's book to the texts of neo-Stalinist writers from the 1950s to the 1970s (Marsh 2007, 525).
} 
the United States. Arguably, the most important character of the book is not the protagonist himself, but the so-called 'Captain', a thinly veiled reincarnation of the legendary artist, musician, and provocateur Sergej Kurëkhin. Whereas the actual Kurëkhin died from a rare heart disease in 1996, Krusanov's Captain has masterfully 'staged' his own death in the nineties. In the futuristic setting of the book (2010/2011) he has turned into a passionate Slavophile and enemy of the West, who is no less fanatical than Islamist militants. He is determined to put a stop to the "Americanization of the world", and to the concomitant advance of a “буржуазный либерализм” [“petty bourgeois liberalism”] (Krusanov 2007, 474). There is no room here to discuss the details of the book's plot, which involves mystery and conspiracy, but when the novel reaches its conclusion, the ingenious intrigues and Internet provocations by the Captain have created irreparable economic and political crises in the United States. America gradually disintegrates, and the novel closes with the Captain sketching the contours of an immense continental Russian empire, which can be built now the archenemy is defeated.

The book derives much of its shocking originality from the fact that a militant patriotism is put in the mouth of the rarely serious Kurëkhin. It should not go unnoticed that Amerikanskaja dyrka was inspired by events from the latter's actual biography. In the months before his death, Kurëkhin famously declared himself a supporter of the National Bolshevist Party (NBP) founded by Aleksandr Dugin and the recently returned émigré writer Ėduard Limonov. The party professed a chaotic blend of radical, revolutionary ideas, and aspired to build an "Импери[я] от Владивостока до Гибралтара на базе русской цивилизации"9 (Dugin and Limonov 1994). Kurëkhin openly sympathized with the movement, although his sympathy may actually have been a form of mockery, or stiob. This peculiar discursive model permeates many of Kurëkhin's pre- and post-perestroika projects, and seems essential to Krusanov's own authorship.

As the cultural anthropologist Alexei Yurchak explains: "[stiob] was a peculiar form of irony that differed from sarcasm, cynicism, derision, or any of the more familiar genres of absurd humor. It required such a degree of overidentification with the object, person, or idea at which this stiob was directed that it was often impossible to tell whether it was a form of sincere support, subtle ridicule, or a peculiar mixture of the two" ${ }^{10}$ (Yurchak 2006, 249-250). Yurchak points out that in late Soviet society, overidentifying with the formal elements of a highly ritualized official culture created the possibility for entering into more creative, and potentially critical, relations with the petrified discourse of the Party and the state. He cites an article written by Kurëkhin in April 1987 for the newspaper Leningradskaja pravda as a classic case in point. Quoting formulaic party language, the text argued that a number of Petersburg rock bands, in which Kurëkhin regularly played, were completely lacking in talent and skills, and even expressed a dangerously bourgeois

\footnotetext{
9 "an Empire from Vladivostok to Gibraltar on the basis of Russian civilization."

${ }^{10}$ For similar descriptions of stiob, see Boym (2002), and Gabowitsch (2009), who examines stiobmechanisms in fascist discourse in post-Soviet Russia; in other parts of the former socialist world stiob seems to have survived as well. See for instance Slavoj Žižek's (2005) comments on the Slovenian band Laibach.
} 
mentality. It took a while for party officials to notice that the article was authored by Sergej Kurëkhin himself, and even then the authorities were at a loss over how to respond. Yurchak (in an article with Dominic Boyer) characterizes their dilemma as follows: "[should] they accuse Kuryokhin of ridiculing the party and its rhetoric or should they continue treating his text as a perfectly sound ideological statement?" (Boyer and Yurchak 2010, 185).

By fictively prolonging the biography of Kurëkhin, Krusanov seems to be reflecting on the possibility of recycling the mechanisms of stiob for an anti-liberal, 'imperialist' agenda in the post-Soviet era. Indeed, in Amerikanskaja dyrka, the Captain couches his anti-Western sympathies in stiob-like hybridizations of irony and (over)identification. In a mysterious scene Kurëkhin, who has been tirelessly fulminating against American greed and pettiness, suddenly appears in the guise of a “карикатурный крючконосый дядя Сэм в звездо-полосатом цилиндре"11 (Krusanov 2007, 642). Later, musing about Russia's radiant future, he proposes “возве[сти] себе новую столицу-на таких топях, на которых может устоять только мечта" 12 (Krusanov 2007, 658). The restoration of the 'Russian empire' to which the Captain has wholeheartedly devoted his 'afterlife' now appears as an illusion or, more precisely, as a chimera in the tradition of the 'Petersburg text' (Toporov 1984). Having 'destroyed America' from behind his computer, Krusanov's character finally fails to turn his imperial fantasy into reality. In these and other passages, ideological fanaticism is destabilized by signs of postmodern simulation and relativism, and fanatical seriousness is confusingly merged with the ironic effects of overidentification.

Novels like Ukus angela and Amerikanskaja dyrka can hardly veil the author's sincere concern with 'ironhandedness' and 'empire'; in public performances Krusanov, like his characters, quixotically commits himself to megalomaniac 'imperial' projects. A vivid example is the open letter that the Petersburg Fundamentalists wrote to Vladimir Putin in early 2001 in which they petitioned the President to include the occupation of Istanbul [Car'grad], the Bosphorus and the Dardanelles amongst the government's geopolitical ambitions (Krusanov et al. 2001). The implied addressee of the open letter was a sort of new Russian emperor, a figure more reminiscent of the dictator Nekitaev from Ukus angela than of the actual Vladimir Putin. Overidentifying with the national assertiveness of the Putin administration, or rather with the exaggerated expectations of the public about his new government, the Fundamentalists pushed political support and trust to the point where it slipped into parody.

In interviews Krusanov has cleverly navigated between the aesthetic, artistic, and political significance of his own books, and many critics have wondered whether or not he espouses the ideological radicalism expressed in his writings and actions. An interesting perspective is provided by Mark Lipovetsky, who reads Krusanov's bestseller Ukus angela in light of the neo-conservative trend in contemporary Russia that "использует постмодернистскую маску иронии" ["uses irony as a postmodern mask"] (Lipovetsky 2008, 490) for advancing ultra-patriotic and even

\footnotetext{
11 "caricatured hook-nosed Uncle Sam, wearing a top hat with stars and stripes."

12 "to build a new capital in marshes on which only dreams can survive."
} 
neo-totalitarian ideas. The suspended modality of stiob, according to him, provides Krusanov and many other 'neo-traditional' and 'post-sots' writers with a suitable alibi for conservatism. Stiob allows the writer to cloak his or her ideological propaganda in a quasi-ironic form, masking political commitment behind the 'illusion' of ironic distance (Lipovetsky 2008, 503).

However, many of Krusanov's writings and projects suggest that the author does not, in fact, employ forms of irony and stiob merely “для отвода глаз” [as a blind] (Lipovetsky 2002), as Lipovetsky argues. Rather, by closely adhering to this ambiguous discursive mode, Krusanov seems to invite his readers to give up their aspirations for a clear-cut dichotomy between a committed and an ironic stance. It is precisely these fascinating amalgams of postmodern irony and ideological enthusiasm that lie at the basis of Krusanov's success, thereby transforming the writer from a member of the artistic underground of the eighties and nineties into a cult figure in the new century.

The blurred border between ideological militancy and postmodern irony, play, and pastiche is by no means limited to the writings of Krusanov and Prokhanov. Even Dmitrij Bykov, who is known as a liberally orientated journalist, film critic, and novelist, displayed in his 2001 novel Opravdanie [Justification] a keen interest in imperial and totalitarian myths. Reviewers have not reached a consensus over the question of whether Bykov criticizes or identifies with the pathological totalitarian nostalgia of his protagonist Rogov. The trend, moreover, surpasses the borders of the literary field. Similar amalgams of radicalism and postmodernism occur in the philosophical essays of the Petersburg Fundamentalist Aleksandr Sekackij and in the graphic art of Aleksej Beljaev-Gintovt, the stylist of Dugin's International Eurasian Movement. In 2008 the latter won the prestigious Kandinsky Prize for his monumental canvasses displaying aggressive and at times fascist imagery. Some of his glorifications of national or Soviet myths and values are obviously intended as comic caricatures, while other paintings appear to be serious improvisations in a Socialist Realist style.

\section{A postmodern aesthetics of radicalism}

The imperialists' works assume that if only Russia could resist the Western-centric ideals of liberalism, pluralism, and mediocrity, it would finally be able to realize its suprahistorical, essentially imperial, identity. Here these writers and artists get their inspiration mainly from Aleksandr Dugin's 'neo-Eurasianism'. Over the past two decades, Dugin has reworked the legacy of the Eurasianist émigré movement of the twenties into a quasi-scientific dogma that continues much of the bipolar Cold War world view. The recent advent of an imperialist trend in art and literature can hardly be understood in isolation from the expanding popularity of Eurasianism, and from Dugin's incredible career. Since the mid-nineties, this philosopher has developed from a peripheral radical and member of occultist subcultures into a fashionable public intellectual and "philosophical DJ" (Polianski 2005), with posts at a number of universities, and connections with the political establishment (Umland 2003). Although it is hard to estimate Dugin's actual influence on political life, it is obvious 
that the 'Dugin phenomenon' reflects a political and cultural climate which is no longer marginal in contemporary Russia (Höllwerth 2007, 192-196).

Original Eurasianists, such as Prince Nikolaj Trubeckoj and Pëtr Savickij (according to Dugin the "евразийский Маркс" ["Eurasian Marx"] and the “евразийский Энгельс" [“Eurasian Engels”] respectively (Dugin 1999, 5)), developed a well-known cultural typology depicting Russia as a unique hybrid of European and Asian civilizations. Russians, in their view, should turn their minds to the Turan (Turk, Mongol, and Finno-Ugric) cultures of Asia, to the spirituality and religiosity of the East, because due to centuries of Tatar domination one could hardly find a "великоросс [...], в жилах которого так или иначе не течет туранская кровь" ${ }^{13}$ (Trubeckoj 1999, 136).

Dugin blends fragments of this tradition with a wide range of esoteric, conspiratorial, and ultra-nationalist teachings. He conceptualizes an unbridgeable rift between the conservative, spiritual, autocratic cultures of Eurasia (mainly Russia), and the rationalist, materialist, liberal proclivities of the 'Atlantic world' (America). As the 'heartland' of the Eurasian continent, Russia, in Dugin's geopolitical theories, is destined to become the leading nation of an immense empire, challenging a 'global yet American' culture of liberalism and democracy. As Dugin has repeatedly declared over the past twenty years: "Россия-либо Империя, либо ее не существует"14 (Dugin 1997).

In Krusanov's Amerikanskaja dyrka, the 'Captain' parrots Dugin's doctrines almost verbatim, claiming that "Россия-империя, и она не может быть ничем иным, кроме империи" "15 (Krusanov 2007, 660). Even so, Krusanov himself declined Dugin's offer to become leader of the Eurasian Youth Movement, as he felt that his primary concerns were literary (personal conversation with the author, 25 November 2009). Once again, this reveals how the imperialist movement is driven by literary rather than political motivations.

Prokhanov also hints at Dugin's theories, obviously basing the jumble of conspiracies in Gospodin Geksogen on Dugin's 1991 essay Velikaja vojna kontinentov [The great war of the continents] (in Dugin 2005). Even the restorative nostalgia of Dmitrij Bykov's character for the "огромные пустые пространства" ["immense empty spaces"] of the lost “Империя" ["Empire”] (Bykov 2005, 52) calls to mind Dugin's frequent veneration of the vast Eurasian lands.

While essential to the ideas of the imperialists, Dugin represents only one of the many voices in the recent drift in Russian culture towards ultra-nationalist, antiliberal, fascist, and revanchist discourses of all shades. Stunningly, these arguments are often legitimized in (highbrow) art and literature, or in fashionable 'counterculture' movements (even when they do not actually oppose the proclivities of the political establishment) (Kukulin 2008). Commentators have often assumed that these artists manipulate their audiences by using playful and artistic discourses as a "glamorous" veneer (Danilin 2006), a "Deckmantel" (Polianski 2005), or an

\footnotetext{
13 "a Great Russian through whose veins Turan blood doesn't flow, one way or another."

14 "Either Russia is an Empire, or she does not exist."

15 "Russia is an empire, and she cannot be anything but an empire."
} 
“алиби” [“alibi”] (Lipovetsky 2008, 503) for advancing totalitarian, or at least neotraditionalist, ideas.

Even if some imperial writers (for instance Prokhanov) may be more serious than others (Krusanov), clear-cut dichotomies between 'genuine intentions' and 'masks', 'veneers', and 'blinds' do not improve our understanding of the ambiguity that is so typical of these authors' positions. Rather than remaining naïvely serious or wildly playful and ironic, these writers and artists seem to have created a new space within the Russian postmodern tradition; harking back to the legacy of pre-perestroika artistic forms like stiob and sots-art, they put forward an aesthetics of radicalism that is often balanced on the very borderline between irony and ideological militancy. By playing the game of ambiguous radicalism, these authors have created an alternative to the detached postmodern attitudes of the 1990s.

Indeed, the public has welcomed these new approaches as a pleasant antidote to the aloofness and perceived cynicism of scandalous, yet politically correct "mushroom-eaters" and "earth-fuckers" such as Pelevin and Sorokin. ${ }^{16}$ By assuming an ideological recklessness, or even a 'Russian madness', as Prokhanov's publisher put it, the "имперский авангард" ["imperial avant-garde"] (Popov 2004) has been able to conquer a central place in Russian popular culture using ultranationalist discourses that, until recently, belonged to the rhetoric of marginal subcultures.

Open Access This article is distributed under the terms of the Creative Commons Attribution Noncommercial License which permits any noncommercial use, distribution, and reproduction in any medium, provided the original author(s) and source are credited.

\section{References}

Aptekman, M. (2006). Kabbalah, judeo-masonic myth, and post-Soviet literary discourse: From political tool to virtual parody. The Russian Review, 65, 657-681.

Boyer, D., \& Yurchak, A. (2010). American stiob: Or what late socialist aesthetics of parody reveal about contemporary political culture in the West. Cultural Anthropology, 25(2), 179-221.

Boym, S. (2002). Stil' PR. Neprikosnovennyj zapas, 6(26). In Žurnal'nyj zal v Russkij žurnal http:// magazines.russ.ru/nz/2002/6/boim.html. Accessed 18 August 2010.

Bykov, D. (2005). Opravdanie. Moscow: Vagrius.

Danilin, P. (2006). Glamurnyj fasizm. Moscow: Evropa.

Danilkin, L. (2002, March 1). Gospodin Geksogen. In Afisha http://www.afisha.ru/book/332/. Accessed 25 September 2010.

Dugin, A. (1997). Pëtr Savickij: Ideolog velikoj Evrazii. In Arktogeja http://arcto.ru/modules.php?name= News\&file=article\&sid=1110. Accessed 25 September 2010.

Dugin, A. (1999). Preodolenie zapada: Ésse o Nikolae Sergeeviče Trubeckom. In N. Trubeckoj, Nasledie Cingiskhana (pp. 5-25). Moscow: Agraf.

Dugin, A. (2005). Konspirologija: Nauka o zagovorakh, sekretnykh obščstvakh, i tajnoj vojne. In Arktogeja http://www.arcto.ru/modules.php?name=News\&file=article\&sid=64. Accessed 10 October 2010 .

\footnotetext{
16 Indeed, postmodernists Pelevin and Sorokin themselves have turned to the theme of empire; see Sorokin's Den' opričnika [Day of the Opričnik, 2006] and Sakharnyj Kreml' [The sugar kremlin, 2008], as well as Pelevin's Ampir V [Empire V, 2007]. These books, however, obviously parody the imperial fashion and do not engage in the stiob-style (over)identifications of the imperialists.
} 
Dugin, A., \& Limonov, Ė. (1994). Programma Nacional-bol'ševistskoj partii. In Nacbol.ru http://www. nbp-info.ru/cat106/index.html. Accessed 25 September 2010.

Epstein, M. (1995). After the future: The paradoxes of postmodernism and contemporary Russian culture. Amherst: University of Massachusetts Press.

Gabowitsch, M. (2009). Fascism as Stiob. Kultura, 4, 3-8.

Groys, B. (1992). The total art of Stalinism. Princeton: Princeton University Press.

Groys, B. (1995). Die Erfindung Rußlands. München: Carl Hanser Verlag.

Höllwerth, A. (2007). Das sakrale eurasische Imperium des Aleksandr Dugin: Eine Diskursanalyse zum postsowjetischen russischen Rechtsextremismus. Stuttgart: ibidem Verlag.

Ivanov, A., \& Aleksandrov, N. (2002, April 9). Prokhanov, kak pevec ruinirovannoj sovetskoj imperii. In GZT.RU http://www.gzt.ru/culture/2002/04/09/164427.html. Accessed 9 October 2010.

Kenžeev, B. (2002, June 14). Lobstery s Borneo, ili khorošij pisatel' Prokhanov. In Russkij žurnal http://old.russ.ru/krug/20020613_kenzh.html. Accessed 14 October 2010.

Krusanov, P. (2007). Triada. St. Petersburg: Amfora.

Krusanov, P., Nazarov, V., Nosov, S., Rekšan, V., et al. (2001, April 13). Imperija, kotoruju ne khočetsja terjat'. In Kuritsyn-weekly http://old.russ.ru/krug/news/20010413.html\#so1. Accessed 18 August 2010 .

Kukulin, I. (2008). Reakcija dissociacii: Legitimacija ul'trapravogo diskursa v sovremennoj rossijskoj literature. In M. Larjuèl' [Laruelle] (Ed.), Russkij nacionalizm: social'nyj i kul'turnyj kontekst (pp. 257-338). Moscow: Novoe literaturnoe obozrenie.

Latynina, A. (2006). Trikster kak spasitel’ Rossii. In Novyj mir http://magazines.russ.ru/novyi_mi/2006/ 2/la11.html. Accessed 14 October 2010.

Lipovetsky, M. (2002). PMS (postmodernizm segodnja). In Znamja http://magazines.russ.ru/znamia/ 2002/5/lipov.html. Accessed 14 October 2010.

Lipovetsky, M. (2008). Paralogii: Transformatsii (post)modernistskogo diskursa v russkoj kul'ture 1920-2000-kh godov. Moscow: Novoe literaturnoe obozrenie.

Lipovetsky, M., \& Borenstein, E. (1999). Russian postmodernist fiction: Dialogue with chaos. Armonk: M. E. Sharpe.

Lipovetsky, M., \& Ėtkind, A. (2008). Vozvraščenie tritona: Sovetskaja katastrofa i postsovetskij roman. Novoe literaturnoe obozrenie, 95, 174-206.

Marsh, R. (2007). Literature, history and identity in post-Soviet Russia, 1991-2006. Oxford: Peter Lang.

Ol'šanskij, D. (2002, April 5). Ot geksogena do galljucinogena. In Vremja MN http://geksogen.ru/ r16.html. Accessed 16 June 2009.

Oushakine, S. (2009). The patriotism of despair: Nation war, and loss in Russia. Ithaca: Cornell University Press.

Polianski, I. (2005, October 12). Der patriotische Konsens gegen "Gelb", "Schwarz" und "Orange": Impressionen und Hintergründe aktueller nationalistischer Diskurse in Russland. In Zeitgeschichte Online http://www.zeitgeschichte-online.de/zol/_rainbow/documents/pdf/zol_int/polianski_natdisk urse.pdf. Accessed 14 October 2010.

Popov, S. (2004). Imperskij avangard. In Khudožestvennyj žurnal http://xz.gif.ru/numbers/54/ impersky-avangard. Accessed 14 October 2010.

Prigodič, V. (2001, June 25). Pervyj roman Imperii, ili Talant ne poddelaeš. In Russkij pereplët http://www.pereplet.ru/kot/31.html. Accessed 10 October 2010.

Prokhanov, A. (2002). Gospodin Geksogen. Moscow: Ad Marginem.

Toporov, V. (1984). Peterburg i peterburgskij tekst russkoj literatury. Učenye zapiski Tartuskogo gos. Universiteta (Vol. 664, pp. 4-29).

Trubeckoj, N. (1999). Nasledie Čngiskhana. Moscow: Agraf.

Umland, A. (2003). Formirovanie fašistskogo "neoevrazijskogo" intellektual'nogo dviženija v Rossii: Put' Aleksandra Dugina ot marginal'nogo èkstremista do vdokhnovitelja postsovetskoj akademičeskoj i političeskoj èlity. Ab Imperio, 3, 289-304.

Yurchak, A. (2006). Everything was forever, until it was no more: The last Soviet generation. Princeton: Princeton University Press.

Žižek, S. (2005). Foreword: They moved underground. In A. Monroe, Interrogation machine: Laibach and NSK (pp. xi-Xv). Cambridge: MIT Press. 